\title{
ALLOMETRIC MODELS FOR ESTIMATING ABOVEGROUND BIOMASS AND BIOMASS ALLOCATION OF CAPIXINGUI TREES (Croton floribundus Spreng.) IN AN AGRISILVICULTURAL SYSTEM ${ }^{1}$
}

\author{
Maria Luiza Franceschi Nicodemo ${ }^{2 *}$, Marcelo Dias Muller ${ }^{3}$, Antônio Aparecido Carpanezzi ${ }^{4}$ and Vanderley \\ Porfírio-da-Silva ${ }^{4}$
}

\footnotetext{
${ }^{1}$ Received on 10.07.2014 accepted for publication on 16.12.2015.

${ }^{2}$ Empresa Brasileira de Pesquisa Agropecuária, Centro de Pesquisa de Pecuária do Sudeste, São Carlos, SP - Brasil. E-mail: $<$ marialuiza.nicodemo@embrapa.br>.

${ }^{3}$ Empresa Brasileira de Pesquisa Agropecuária, Centro Nacional de Pesquisa de Gado de Leite, Coronel Pacheco, MG - Brasil. E-mail: <marcelo.muller@embrapa.br>.

${ }^{4}$ Empresa Brasileira de Pesquisa Agropecuária-CNPF,Embrapa Florestas, Colombo,PR-Brasil. E-mail: <antonio.carpanezzi@embrapa.br>. and <vanderley.porfirio@embrapa.br>

${ }^{*}$ Corresponding author.
}

\begin{abstract}
The objective of this study was to select allometric models to estimate total and pooled aboveground biomass of 4.5-year-old capixingui trees established in an agrisilvicultural system. Aboveground biomass distribution of capixingui was also evaluated. Single- (diameter at breast height [DBH] or crown diameter or stem diameter as the independent variable) and double-entry (DBH or crown diameter or stem diameter and total height as independent variables) models were studied. The estimated total biomass was 17.3 t.ha-1, corresponding to $86.6 \mathrm{~kg}$ per tree. All models showed a good fit to the data $\left(\mathrm{R}^{2}\right.$ ad $\left.>0.85\right)$ for bole, branches, and total biomass. DBH-based models presented the best residual distribution. Model $\ln \mathrm{W}=\mathrm{b} 0+\mathrm{b} 1 * \ln D B H$ can be recommended for aboveground biomass estimation. Lower coefficients were obtained for leaves $\left(\mathrm{R}^{2}{ }_{\text {ad }}>82 \%\right)$. Biomass distribution followed the order: bole $>$ branches $>$ leaves. Bole biomass percentage decreased with increasing DBH of the trees, whereas branch biomass increased.
\end{abstract}

Keywords: Agroforestry systems; Integrated production systems; Modeling.

\section{MODELOS ALOMÉTRICOS PARA ESTIMAÇÃO DE BIOMASSA AÉREA E ALOCAÇÃO DE BIOMASSA DE CAPIXINGUI (Croton floribundus Spreng.) EM UM SISTEMA SILVIAGRÍCOLA}

\begin{abstract}
RESUMO - O objetivo deste estudo foi selecionar equações alométricas para predição da biomassa aérea total e nos compartimentos aéreos de capixingui com 4,5 anos estabelecidas em um sistema silviagrícola. Foram tomadas medidas dendrométricas e utilizou-se o método destrutivo para a estimação da biomassa, com a separação dos componentes em tronco, galhos efolhas. Foram ajustados e comparados quatro modelos alométricos, sendo dois de simples entrada e dois de dupla entrada. Como variáveis preditoras foram considerados o diâmetro à altura do peito (DAP), diâmetro de colo (D colo), diâmetro de copa (Dc) e altura total (H). A biomassa total estimada foi de 17,3 t.ha-1, equivalente a $86,6 \mathrm{~kg}$ por árvore. Todos os modelos apresentaram ajustes satisfatórios $\left(R_{a j}^{2}>0,85\right)$ para tronco, galhos e biomassa total. As equações para biomassa total que tiveram como variável preditora o DAP apresentaram as melhores distribuições de resíduos. O modelo $\ln W=b 0+b 1 * \ln D A P$ pode ser recomendado para estimativa de biomassa aérea. Para folhas, os coeficientes foram menores $\left(R_{a j}^{2}>82 \%\right)$. A distribuição da biomassa nos componentes seguiu a ordem: tronco $>$ galhos $>$ folhas. A percentagem de biomassa no tronco decresceu com o aumento do DAP das árvores enquanto que a biomassa nos galhos aumentou.
\end{abstract}

Palavras-chave: Modelagem; Sistemas agroflorestais; Sistemas de integração da produção. 


\section{INTRODUCTION}

The selection of technologies for production systems should consider ways to reduce the impacts on water use, soil and biota and should be directed toward the regeneration of ecosystem services which are associated with increased biodiversity (TILMAN et al., 2011; BALMFORD et al., 2012). Agroforestry systems based on reconciling production and environmental conservation have been encouraged by public policies such as the Low-Carbon Agriculture Program (Agricultura de Baixa Emissão de Carbono - ABC). Agrisilvicultural system is among those, consisting of the combination of crops and woody species (NAIR, 1985).

Eucalyptus is the most common tree species used in agroforestry systems in Brazil (VENTURIN et al., 2010). In an attempt to diversify the forest base by introducing native species (RUSCHEL et al., 2003; CARPANEZZI et al., 2010), other species have been tested in these systems (NICODEMO et al., 2009; MELLOTO etal., 2009). One such species is capixingui (Croton floribundus Spreng.), a pioneer tree species found mainly in seasonal semideciduous forests in the southeastern region of Brazil and in northern Paraná. This plant has some interesting characteristic for agroforestry systems, such as simple seedling production, high survival rates, rusticity, and moderate to rapid growth. In addition, it is a melliferous species which is of high value to the beekeeping industry and its wood can be used for construction, cellulose production, for medicinal purposes (CARVALHO, 2003; GOUVEIA et al., 2007) and more recently for the production of briquettes.

Agroforestry systems are dynamic and require interventions such as thinning and pruning to regulate the competition between its components (JOSE et al., 2004). Therefore, estimating aboveground biomass from simple measures is interesting for the producer since it allows to predict the amount of timber forest products to be obtained with the intervention. Forest biomass can be evaluated by felled trees or by estimating biomass using allometric models. Direct determination is labor intensive, complex, time consuming, and expensive. Allometric models are developed by fitting regression equations (FEREZ, 2010). These models have been developed for mixed forest stands (BROWN, 1997; TIEPOLO et al., 2002; CHAVE et al., 2005; FEREZ, 2010) and for individual species (KUMAR et al., 1998; KAONGA and BAYLISS-SMITH, 2010), and are routinely used.
Technical projects involving agrisilvicultural system include the estimation of the development of tree components and expected revenue generation. Biomass estimates are used to calculate the amount of carbon captured by the system and to predict the amount of potentially available forest product. Few allometric equations have been developed for native Brazilian tree species (SALIS et al., 2004; BARBEIRO et al., 2009; PADILHA, 2011) and we found no model for native tree species grown in agrisilvicultural system. The objective of the present study was to select allometric equations for estimating total aboveground biomass of 4.5-year-old capixingui species established in an agrisilvicultural system, as well as to evaluate the aboveground biomass distribution in different compartments.

\section{MATERIALAND METHODS}

The study was conducted in the municipality of São Carlos, SP (latitude $22^{\circ} 1^{\prime}$ South and longitude $47^{\circ} 53^{\prime}$ 'West). The climate of the region is classified as Cwa-Awa (KÖPPEN), with the dry season from April to September. The average annual temperature is 21.2 ${ }^{\circ} \mathrm{C}$, average annual relative humidity is $75.6 \%$, and average annual rainfall is $1362 \mathrm{~mm}$. The topography is smooth, with slopes of $3 \%$ to $5 \%$ and a mean altitude of $860 \mathrm{~m}$. The area was formed by Urochloa decumbens on Red-Yellow Latosol. The agroforestry system was implemented in January 2008, with five rows of trees interspersed with annual crops. Each row was formed by three lines of trees along the terrain level. The trees were planted at a distance of $2.5 \times 2.5 \mathrm{~m}$, resulting in 600 trees/ha. Annual crops were planted in the 17$\mathrm{m}$ inter-spaces between the bands of trees. The forest species planted at random in the central line were: angico (Anadenanthera colubrina), canafístula (Peltophorum dubium), ipê-felpudo (Zeyheria tuberculosa), jequitibá-branco (Cariniana estrellensis), and pau-jacaré (Piptadenia gonoacantha). To obtain higher plant stems, mutambo (Guazuma ulmifolia) and capixingui were planted alternately in the marginal lines, for a total of 200 trees/ha per species. The trees were fertilized for the first 18 months. Silvicultural practices included the combat of leaf-cutting ants and herbaceous plant control. The crops planted in the bands between rows were managed conventionally and in these areas soil corrections were supported by annual soil analysis. 
Capixingui and mutambo were pruned in November 2010,35 months after planting the trees. The pruning criteria were the conservation of at least $50 \%$ of the green crown, removing the branches below the point where the stem measured 6 to $8 \mathrm{~cm}$ in diameter. The crops planted after pruning showed low performance and thinning was recommended to control competition. Thinning was performed between June 13 and July 3,2012 . Because capixingui has a lower crown insertion height and lower apical dominance, impairing mechanical treatment of the plantation area, it was chosen for thinning. The mean wood basic density of capixingui, which was calculated by dividing dry weight by green volume, was $0.36 \mathrm{~g} \mathrm{~cm}^{-3}$ on the occasion of tree felling (Lima, I.L., personal communication, May 7, 2013).

Plots containing 79 of the 802 existing capixingui trees $(10 \%)$ were delimited for measurements. The diameter at breast height $(\mathrm{DBH})$ and total height were determined with a measuring tape $(\mathrm{DBH}=$ circumference/ð) and a telescopic pole in May 2012. The DBH of trees with multiple, bifurcated boles or crown formation below a height of $1.30 \mathrm{~m}$ was calculated as follows: the basal area for each bole was calculated and the sum of basal areas was related to a cumulative value of $\mathrm{DBH}$.

The capixingui trees were divided into four diameter size classes to account for variations in the stand. Next, three trees were selected per diameter size class for biomass estimation. The following measurements were obtained from each selected tree: stem diameter (10-15 cm from the ground), $\mathrm{DBH}$, crown diameter obtained as the mean of orthogonal measurements taken in the N-S and W-E directions, and total height.

The trees were cut with a chainsaw at $10 \mathrm{~cm}$ from the ground onto a plastic canvas. First, leaves and branches were removed. The branches were divided into three diameter size classes: thin $(<3 \mathrm{~cm})$, medium ( 3 to $15 \mathrm{~cm})$, and thick $(>15 \mathrm{~cm})$. The leaves and branches were weighed on a digital scale in the field immediately after felling. Three subsamples of leaves and branches were obtained from each size class to calculate the dry matter. The bole was divided into sections of 1.5 $\mathrm{m}$, numbered on the lower part of the tree. If there were bifurcations, shorter segments were taken. The weight of the segments was measured in the field with a digital scale. Two subsamples were obtained from each segment to calculate the dry weight. Thus, the subsamples were oven-dried at $60^{\circ} \mathrm{C}$ until a constant weight was obtained.
Total biomass of the tree compartments was calculated as the percentage of dry weight of the samples using the following formula: dry weight $=($ dry weight $/$ green weight) $* 100$

In addition, the data of the 79 trees were used to develop a hypsometric equation that related height to $\mathrm{DBH}$. This equation reduces the time necessary to characterize the capixingui production systems, provided the conditions for which the equation was generated are respected. The following model was used: $\ln \mathrm{Ht}$ $=\beta 0+\beta 1 *(1 / \mathrm{DBH})$, where $H t=$ estimated total height, $\beta O$ and $\beta 1=$ coefficients of the equation, and $\mathrm{DBH}$ $=$ diameter at breast height.

To estimate total biomass, four allometric models were fit to the diameter data (DBH, stem diameter, crown diameter), total height and biomass, including two doubleentry (two independent variables) and two single-entry (one independent variable) models, according to: (1) $\ln \mathrm{P}=\mathrm{b} 0+\mathrm{b} 1 * \ln \mathrm{D}+\mathrm{b} 2 * \ln \mathrm{H}$ (Schumacher and Hall); (2) $\ln \mathrm{P}=\mathrm{b} 0+\mathrm{b} 1 * \ln \mathrm{D}+\mathrm{b} 2 * \mathrm{D}($ Brenac $) ;(3) \ln \mathrm{P}=\mathrm{b} 0+\mathrm{b} 1 * \ln \left(\mathrm{D}^{2} \mathrm{Ht}\right)$ (Spurr); and (4) $\ln \mathrm{P}=\mathrm{b} 0+\mathrm{b} 1 * \ln \mathrm{D}$ (Koperzky and Gehrhardt), where: $\mathrm{P}=$ biomass $\left(\mathrm{t} \mathrm{ha}^{-1}\right)$; $\mathrm{D}$ : diameter (diameter at breast height, $\mathrm{cm}$; stem diameter, $\mathrm{cm}$; crown diameter, m); H: total height (m). Source: Soares et al. (2007). In the case of the allometric equations used to estimate the biomass of tree components, only DBH was computed for the diameter data, using the same models.

The models were selected based on the adjusted coefficient of determination $\left(\mathrm{R}^{2}{ }_{\text {ad }}\right)$, standard error of the estimate $\left(\mathrm{S}_{\mathrm{yx}}\right)$, and graphic distribution of residuals. The coefficient of determination expresses the total variation in the data explained by the model, the standard error indicates sampling-induced errors, and graphical analysis of the residuals shows trends of biomass underestimation or overestimation by the model.

\section{RESULTS}

The model of hypsometric relationship, $\ln \mathrm{Ht}=\beta 0$ $+\beta 1 *(1 / \mathrm{DBH})$, used to estimate total tree height, provided an $\mathrm{R}_{\text {ad }}^{2}=0.72$ and $\mathrm{S}_{\mathrm{xy}}=0.094$, with coefficients $\beta 0=$ 2.4732 and $\beta 1=-5.0503$. Figure 1 illustrates the relationship between height and diameter.

In general, the models tested for estimating total aboveground biomass of the trees showed a good fit to the data $\left(\mathrm{R}_{\text {ad }}^{2}>0.92\right.$; Table 1$)$, which suggests they are effective predictors of aboveground biomass.

Revista Árvore, Viçosa-MG, v.40, n.2, p.279-288, 2016

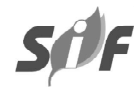




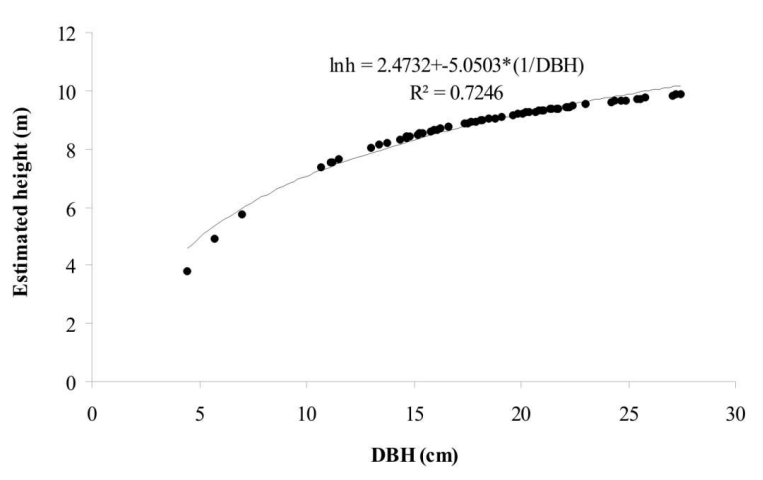

Figure 1 - Relationship between height and diameter at breast height (DBH) of 4.5-year-old capixingui established in an agrisilvicultural system.

Figura 1-Relação entre altura e diâmetro plantas de capixingui em um sistema silviagrícola de 4,5 anos de idade.

Figure 2 shows the residuals of all equations adjusted as a function of the different variables studied. The graphs confirm the better performance of the equations adjusted as a function of $\mathrm{DBH}$.

The models used for estimating biomass of tree components showed a good fit to the data $\left(\mathrm{R}^{2}\right.$ ad $>0.82$; Table 2). Model fit was better for total biomass, bole and branches biomass than foliage biomass.
Biomass distribution in the different tree components followed the order: bole $>$ branches $>$ leaves (Figure 3).

\section{DISCUSSION}

\subsection{Allometric equations for total biomass}

The model of hypsometric relationship, $\ln \mathrm{Ht}=\beta 0$ $+\beta 1^{*}(1 / \mathrm{DBH})$, used to estimate total tree height, showed good fit (Figure 1). In the study of Soares et al. (2011), this model also showed the best fit for nine of 11 native species from the city of Viçosa, Minas Gerais, with $\mathrm{R}_{\text {ad }}^{2}$ values ranging from 0.70 to 0.92 between species. The possibility of using DBH to estimate tree height is a time-saving approach for the characterization of capixingui since height measurements are more labor intensive and time-consuming than the measurement of DBH.

The mean height and DBH were $8.06 \mathrm{~m}$ and 17.55 $\mathrm{cm}$, respectively. The frequency distribution obtained for the capixingui stand was unimodal, with $85 \%$ of the trees in the DBH class of 14 to $27.9 \mathrm{~cm} ; 15 \%$ of the individuals did not exceed a DBH of $13.9 \mathrm{~cm}$. This distribution is typical of even-aged planted forests and reflects processes of competition and genetic

Table 1 - Statistical parameters of the allometric models used for estimating biomass of 4.5-year-old capixingui established in an agrisilvicultural system as a function of diameter at breast height $(\mathrm{DBH}, \mathrm{cm})$, stem diameter $(\mathrm{Ds}, \mathrm{cm})$, crown diameter $(\mathrm{Dc}, \mathrm{cm})$, and total height $(\mathrm{H}, \mathrm{m})$.

Tabela 1 - Parâmetros estatísticos da modelagem de equações alométricas para estimação de biomassa de capixingui estabelecidas em um sistema silviagrícola, aos 4,5 anos de idade, em função do DAP - diâmetro à altura do peito (cm), D colo - diâmetro do colo (cm), Dc-diâmetro de copa (cm) e H-altura total (m).

\begin{tabular}{|c|c|c|c|c|c|}
\hline \multirow[t]{2}{*}{ Equation } & \multicolumn{3}{|c|}{ Coefficients } & \multirow[t]{2}{*}{$\mathrm{R}_{\text {ad }}^{2}$} & \multirow[t]{2}{*}{$\mathrm{S}_{\mathrm{xy}}$} \\
\hline & $\beta_{0}$ & $\beta_{1}$ & $\beta_{2}$ & & \\
\hline \multicolumn{6}{|c|}{ Predictor variables: $\mathrm{DBH}$ and $\mathrm{H}$} \\
\hline 1 & -2.7218 & 2.6172 & -0.2518 & 0.9850 & 0.2098 \\
\hline 2 & -2.7652 & 2.3953 & 0.0076 & 0.9850 & 0.2099 \\
\hline 3 & -3.3561 & 0.9666 & & 0.9801 & 0.2187 \\
\hline 4 & -2.8564 & 2.4771 & & 0.9834 & 0.1999 \\
\hline \multicolumn{6}{|c|}{ Predictor variables: Ds and $\mathrm{H}$} \\
\hline 1 & -4.8627 & 1.2419 & 2.5268 & 0.9587 & 0.3484 \\
\hline 2 & -6.7739 & 4.4830 & -0.1142 & 0.9507 & 0.3805 \\
\hline 3 & -4.6437 & 1.0933 & & 0.9423 & 0.3724 \\
\hline 4 & -4.3460 & 2.8617 & & 0.9168 & 0.4473 \\
\hline \multicolumn{6}{|c|}{ Predictor variables: Dc and $\mathrm{H}$} \\
\hline 1 & -2.6662 & 1.6199 & 2.0887 & 0.9800 & 0.2427 \\
\hline 2 & -0.3648 & 4.5547 & -0.4781 & 0.9710 & 0.2921 \\
\hline 3 & -1.5995 & 1.1298 & & 0.9706 & 0.2658 \\
\hline 4 & -0.2697 & 2.9606 & & 0.9436 & 0.3685 \\
\hline
\end{tabular}

Where: $\mathrm{R}^{2}{ }_{\mathrm{ad}}=$ adjusted coefficient of determination; $\mathrm{S}_{\mathrm{xy}}=$ standard error of the estimate. 

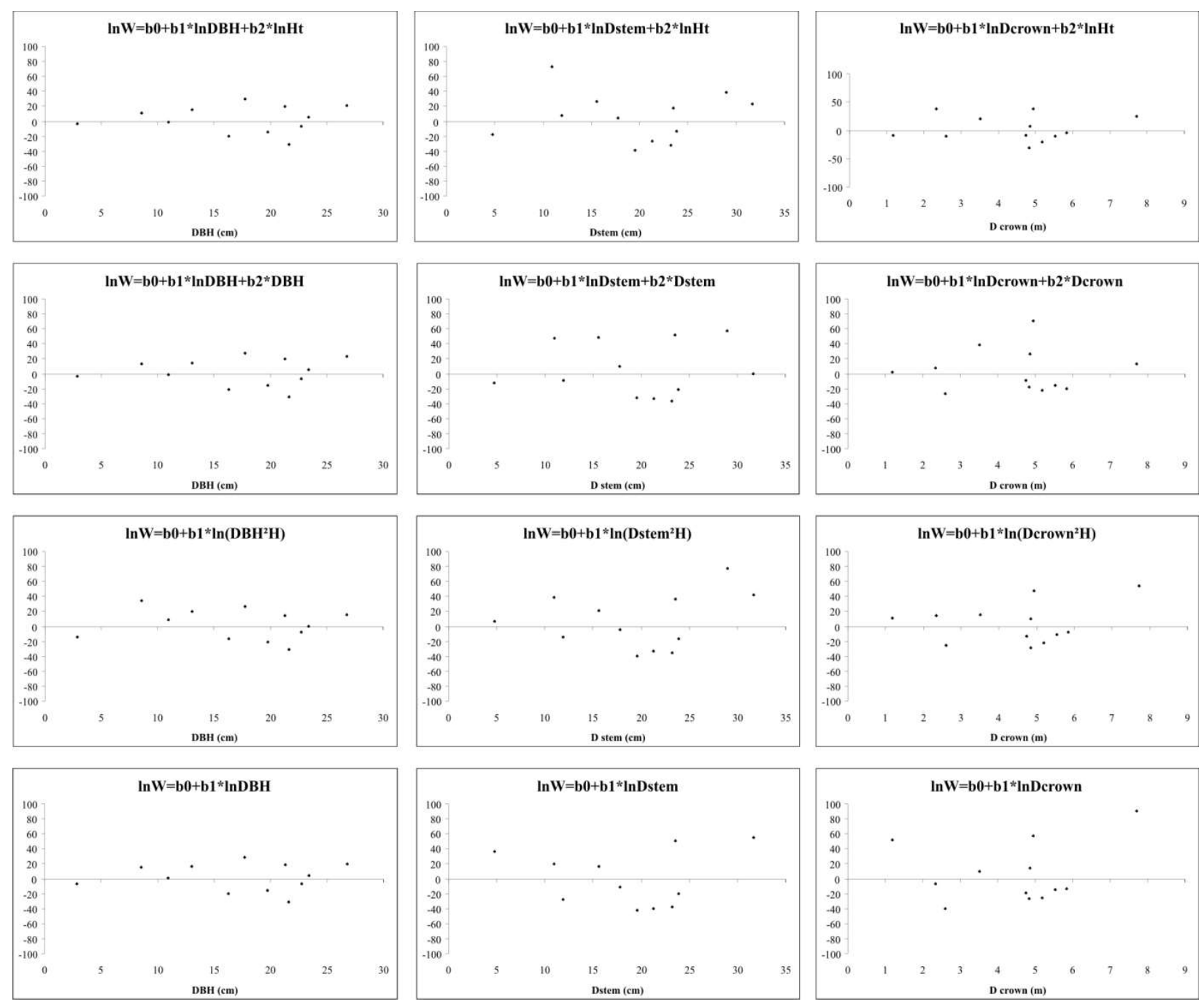

Figure 2 - Residual plot of the four models as a function of different predictor variables (diameter at breast height, DBH; stem diameter, Ds; crown diameter, Dc).

Figura 2 - Distribuição gráfica de resíduos para os quatro modelos testados em função de diferentes variáveis preditoras (em função do DAP - diâmetro à altura do peito, D colo - diâmetro do colo, Dc-diâmetro de copa).

variability of the species (RÉ, 2011). Carvalho (2003) reported $\mathrm{DBH}$ values for two homogenous capixingui stands. In Telêmaco Borba (PR, Brazil), the DBH was $7.8 \mathrm{~cm}$ at 8 years. The narrow row spacing $(4,444$ trees/ ha) may have compromised the development of these trees. In contrast, in Ilha Solteira (SP, Brazil), the mean DBH was $6.9 \mathrm{~cm}$ at one year after planted, at a density of 1,111 trees/ha. It is possible that in the present study the trees benefitted from the wider spacing and the presence of fertilizer residue of the crops between rows.

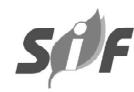

The estimated total biomass was 17.3 t.ha-1, corresponding to $86.64 \mathrm{~kg} /$ tree. Approximately $96 \%$

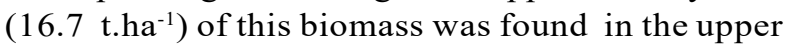
diameter size classes (14-20.9 and 21-27.9), where there is a higher frequency of individuals per hectare. The production of aboveground biomass was higher than that obtained for 6-year-old Croton urucurana in a reforestation area of naturally low fertility, which produced on average $32.6 \mathrm{~kg} /$ tree at a density of 1,667 plants/ ha (FEREZ, 2010). In that study, the mean individual total (aboveground + belowground) biomass production

Revista Árvore, Viçosa-MG, v.40, n.2, p.279-288, 2016 
Table 2 - Statistical parameters of the allometric models used for estimating biomass of tree components of 4.5-year-old capixingui established in an agrisilvicultural system.

Tabela 2 - Parâmetros estatísticos da modelagem de equações alométricas para estimação de biomassa de componentes de capixingui estabelecidos em um sistema silviagrícola, aos 4,5 anos de idade.

\begin{tabular}{|c|c|c|c|c|c|}
\hline \multirow[t]{2}{*}{ Equation } & \multicolumn{3}{|c|}{ Coefficients } & \multirow[t]{2}{*}{$\mathrm{R}^{2} \mathrm{ad}$} & \multirow[t]{2}{*}{ Sxy } \\
\hline & $\beta_{0}$ & $\beta_{1}$ & $\beta_{2}$ & & \\
\hline \multicolumn{6}{|l|}{ Bole } \\
\hline 1 & -15.0651 & 0.6805 & 2.4295 & 98.79 & 0.1732 \\
\hline 2 & -2.7771 & 2.2878 & -0.0394 & 95.96 & 0.3162 \\
\hline 3 & -5.5287 & 0.6790 & & 95.85 & 0.3041 \\
\hline 4 & -1.7473 & 1.5941 & & 93.16 & 0.3906 \\
\hline \multicolumn{6}{|l|}{ Branches } \\
\hline 1 & -20.1640 & 0.7204 & 3.1347 & 92.48 & 0.5340 \\
\hline 2 & -4.4605 & 2.8962 & -0.0566 & 90.15 & 0.6115 \\
\hline 3 & -7.4997 & 0.8100 & & 88.01 & 0.6101 \\
\hline 4 & -2.9805 & 1.8992 & & 85.00 & 0.6825 \\
\hline \multicolumn{6}{|l|}{ Leaves } \\
\hline 1 & -16.9614 & 0.7911 & 2.3654 & 85.87 & 0.6664 \\
\hline 2 & -4.8686 & 2.2690 & -0.0334 & 83.25 & 0.7255 \\
\hline 3 & -7.9701 & 0.7149 & & 82.19 & 0.6767 \\
\hline 4 & -3.9952 & 1.6806 & & 81.66 & 0.7202 \\
\hline
\end{tabular}

of 20 species of a seasonal semideciduous forest was a mean total biomass of $35 \mathrm{~kg} /$ tree (FEREZ, 2010). Soil fertility and provenance, among other reasons, might increase tree production.

For the four models studied (Tabela 1), the best fit was obtained when DBH was included in the model, with $\mathrm{R}_{\text {ad }}^{2}$ values ranging from 0.985 for models 1 and 2 to 0.9801 for model 3 . The use of crown diameter also provided satisfactory fits, with $\mathrm{R}_{\text {ad }}^{2}$ ranging from 0.98 for model 1 to 0.9436 for model 4 . Stem diameter was the least efficient variable to fit the models tested, despite the observation of satisfactory $\mathrm{R}^{2}$ ad values which

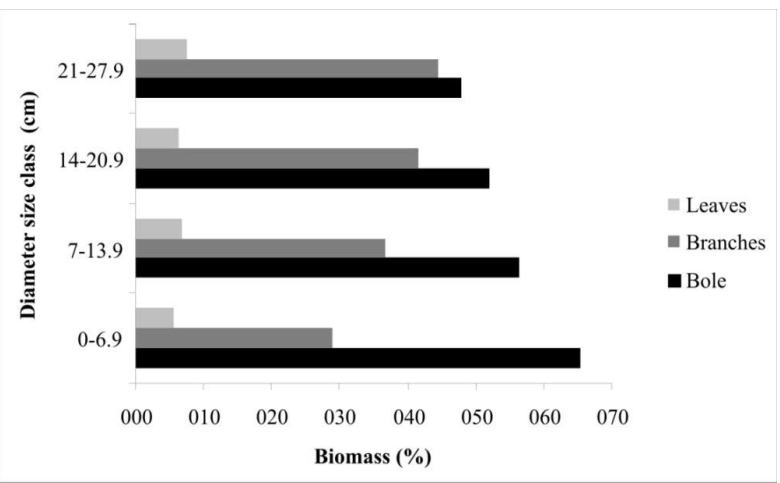

Figure 3 - Distribution of aboveground biomass according to diameter size class.

Figura 3-Distribuição da biomassa aérea por classe diamétrica. ranged from 0.9587 for model 1 to 0.9168 for model 4. The lowest $S_{x y}$ values were obtained for the models adjusted as a function of DBH (0.1999 for model 4 and 0.2187 for model 3 ). When the models were adjusted as a function of crown diameter, $\mathrm{S}_{\mathrm{xy}}$ ranged from 0.2427 (model 1) to 0.3685 (model 4). The highest $S_{x y}$ values were obtained when stem diameter was used $(0.3484$ for model 1 and 0.4473 for model 4).

For the models adjusted as a function of DBH, the statistical parameters were closely similar (0.9801 $<\mathrm{R}_{\text {ad }}^{2}<0.9850$ and $\left.0.1999<\mathrm{S}_{\mathrm{xy}}<0.2099\right)$. Among the double-entry models ( 1 and 3 ), model 1 showed the best fit, whereas among the single-entry models ( 2 and 4 ), model 4 provided the best $\mathrm{R}^{2}$ ad and $\mathrm{S}_{\mathrm{xy}}$ values. For the models adjusted as a function of stem diameter and crown diameter, model 1 (double entry) showed the best fit.

For the equations adjusted as a function of $\mathrm{DBH}$ (Table 1 and Figure 2), model 4 (single entry) was similar to the other models, a finding that supports its indication for biomass estimation since it is simpler while presenting the same efficiency. Barbeiro et al. (2009) also recommended the use of a single-entry equation using DBH to estimate total biomass of Nectandra grandiflora, with an $\mathrm{R}_{\text {ad }}^{2}$ of 0.9458 and $\mathrm{S}_{\mathrm{xy}}$ of 0.1969. However, total biomass included belowground biomass in that study. Kumar et al. (1998) tested similar models for estimating

Revista Árvore, Viçosa-MG, v.40, n.2, p.279-288, 2016 
biomass in silvopastoral and woodlot experiments involving different tree species. The results obtained for the single-entry model (biomass as a function of $\mathrm{DBH}$ ) and double-entry model (biomass as a function of DBH and height) were similar and satisfactory. According to Kaonga and Bayliss-Smith (2010), biomass depends mainly on tree diameter since the bole accumulates most of the biomass, although the inclusion of height in diameter-based prediction equations may describe more accurately the variability in aboveground biomass. The authors suggested that tree biomass of other species with similar diameter and height ranges and crown architecture could be estimated using regression equations developed for different species grown in the same environment provided they are regularly calibrated. However, wood density is another important factor to be considered when selecting the equations (CAMPBELL et al., 1985).

\subsection{Allometric equations for biomass of tree components}

The best fits for estimating biomass of tree components (Table 2) were obtained with double-entry equation (1) $(\ln \mathrm{W}=\mathrm{b} 0+\mathrm{b} 1 * \ln \mathrm{DBH}+\mathrm{b} 2 * \ln \mathrm{H})$, which showed a high capacity to explain the variability in the trees included in the sample. Although the doubleentry models (as a function of $\mathrm{DBH}$ and $\mathrm{H}$ ) provided the highest $\mathrm{R}_{\text {ad }}^{2}$ and lowest $\mathrm{S}_{\mathrm{xy}}$, the single-entry models (including only $\mathrm{DBH}$ as the independent variable) also showed satisfactory fits for bole biomass, which correspond to the largest part of the tree (Figure 3 ). Barrichello et al. (2005) obtained satisfactory fits (0.83 $<\mathrm{R}^{2}$ ad $<0.99$ and $\left.0.125<\mathrm{S}_{\mathrm{xy}}<0.496\right)$ for the singleentry equation $\ln \mathrm{W}=\mathrm{b} 0+\mathrm{b} 1 * \ln \mathrm{DBH}$ (Koperzky and Gehrhardt) when estimating tree component biomass of acácia-negra (Acacia mearnsii), including leaves $\left(\mathrm{R}^{2}{ }_{\mathrm{ad}}=0.94 ; \mathrm{S}_{\mathrm{xy}}=0.308\right)$. Barbeiro et al. (2009) attributed the high $\mathrm{S}_{\mathrm{xy}}$ of the equations developed for the leaf component of Nectandra grandiflora to the large heterogeneity in foliage biomass of similar size trees, which presented irregular crown architecture, a fact that may also apply to capixingui. The authors suggested that the models tested were not adequate for predicting leaf biomass.

\subsection{Biomass partition}

The proportion of biomass accumulated in the bole (Figure 3) decreased with increasing diameter size class (from $65.4 \%$ in class $0-6.9 \mathrm{~cm}$ to $47.88 \%$ in class
$21-27.9 \mathrm{~cm})$ and biomass accumulated in the branches increased (from $27.95 \%$ in class $0-6.9 \mathrm{~cm}$ to $44.54 \%$ in class 21-27.9 cm).

Foster and Melo (2007) collected data from 120 trees belonging to 44 species. DBH ranged from 4.5 to $57.5 \mathrm{~cm}$ in nine heterogeneous reforestation areas and tree age ranged from 5 to 36 years. Three capixingui specimens, considered a fast-growing species, were sampled. Aboveground biomass accounted for $75.5 \%$ of total biomass. Trees with this growth pattern presented on average $6.5 \pm 4.8 \%$ of their biomass in leaves $(8.2 \%$ of aboveground biomass), $39.9 \pm 16.9 \%$ in branches ( $49.8 \%$ of aboveground biomass), $33.8 \pm 14.7 \%$ in the bole ( $42.1 \%$ of aboveground biomass), and $19.8 \pm 6.7 \%$ in roots. No detailed data according to species or age were available. These results are compatible with the present findings, reflecting a greater maturity of the individuals collected in that study. Results similar to those obtained here have been reported by Kumar et al. (1998) for different species grown in silvopastoral systems in India. Furthermore, Drumond et al. (2007) and Silva and Sampaio (2008) observed the same pattern for woody caatinga species. Barrichello et al. (2005) and Schneider et al. (2005) reported the same pattern for acácia-negra in southern Brazil.

Foliage biomass increased by $25 \%$ with increasing diameter size class (from $5.7 \%$ in class $0-6.9 \mathrm{~cm}$ to $7.6 \%$ in class 21-27.9), although the contribution of this component to total biomass was still low. Kaonga and Bayliss-Smith (2010) found that less than 3\% of aboveground biomass is allocated to leaves in tropical forest species, which is probably a consequence of tree architecture, phenology and age. Barichello et al. (2005) showed that leaves accounted for $3.39 \%$ of aboveground biomass in an 8-year-old acácia-negra stand. According to the authors, carbohydrates are allocated to the crown during the early stages of forest development and their proportions in wood and bark increase gradually with age. This observation is supported by the findings of Caldeira et al. (2001) who detected $20 \%$ dry matter of total aboveground biomass in the leaves of a 2.4-year-old acácia-negra stand.

The spacing used in agroforestry systems may alter biomass distribution when compared to denser systems. Gutmanis (2004) studied a silvopastoral system with two densities of 30-year-old Pinus elliottii. The author observed $4.65 \%$ of aboveground biomass in the needles and cited data from Soave (1990), who found

Revista Árvore, Viçosa-MG, v.40, n.2, p.279-288, 2016 
$7.4 \%$ of aboveground biomass in the needles of a 31 year-old pure $P$. elliotti stand. The bole accounted for $77-78 \%$ of aboveground biomass in the silvopastoral system and for $79 \%$ in the pure forest plantation. The contribution of leaves was higher in wider spaced plantations, which is a characteristic of integrated systems.

Although Gutmanis (2004) concluded that the greater allocation of energy to branch production is unfavorable in silvopastoral systems focusing on wood products, the fact that that capixingui exhibits sympodial growth and is a heliophilic and pioneer species should be taken into consideration. After a certain amount of biomass is accumulated in the stem/bole, energy is allocated to the formation of the canopy (branch production), which is expected for a sympodial species. This can be seen in Figure 3, in which the proportion of branch biomass in relation to bole biomass increases in larger diameter size classes.

The partitioning of woody biomass between stem and branches decreased with increasing DBH of the trees, increasing the amount of woody biomass in branches and limiting the bole height. As a consequence, the use of this species in agrisilvicultural system would be restricted, especially for carbon sequestration and immobilization in wood products, since pruning is a necessary silvicultural practice to regulate competition for light exerted by the tree canopy on agricultural or forage components of these systems. The practice of pruning $50 \%$ of the green crown in trees with a $\mathrm{DBH}$ $>14 \mathrm{~cm}$ could lead to the removal of more than $25 \%$ of woody biomass, corresponding exactly to the fraction where the highest carbon concentration is found. Rather than using pruning to control competition in systems composed of capixingui, the thinning of this species could be predicted and the material collected could be used for the production of briquettes.

\section{CONCLUSIONS}

All models provided a satisfactory fit for predicting biomass. Therefore, we recommend the use of model $4(\ln \mathrm{W}=\mathrm{b} 0+\mathrm{b} 1 * \ln \mathrm{DBH})$ for estimating tree biomass in capixingui grown in an agrisilvicultural system because of its simplicity and easy data collection and transformation. The variable DBH should be used since it provided the best fit of the models tested.

The estimated total biomass of capixingui was 17.3 t.ha-1, corresponding to $86.6 \mathrm{~kg}$ per tree. Aboveground biomass production follows the order bole $>$ branches $>$ leaves in 4.5-year-old capixingui. The contribution of branches increases with diameter size class.

\section{REFERENCES}

BALMFORD, A.; GREEN, R.; PHALAN, B. What conservationists need to know about farming. Proceedings of the Royal Society B, v.279, p.2714-2724, 2012.

BARBEIRO, L.S.S.; VIEIRA, G.; SANQUETTA, C.R. Equações para estimativa da biomassa individual de Nectandra grandiflora Ness (canelaamarela). Floresta, v.39, n.4, p. 833-843, 2009.

BARICHELLO, L.R.; SCHUMACHER, M.V.; VOGEL, H.L.M. Quantificação da biomassa de um povoamento de Acacia mearnsii De Wild. na região sul do Brasil. Ciência Florestal, v.15, n.2, p.129-135, 2005.

BROWN, S. Estimating biomass and biomass change in tropical forests: a primer. Rome: FAO, 1997. 55p. (Forestry paper, 134).

CALDEIRA, M.V.W.; SCHUMACHER, M. V. ; RONDON NETO, R. M. Quantificação da biomassa acima do solo de Acacia mearnsii De Wild., procedencia Batemans Bay - Austrália. Ciência Florestal, v.11, n.2, p.79-91, 2001.

CAMPBELL, J.S.; LIEFFERS, V.J.; PIELOU, E.C. regression equations for estimating single tree biomass of trembling aspen: assessing their applicability to more than one population. Forest Ecology and Management, v.11, p.283-295, 1985.

CARVALHO, P.E.R. Espécies arbóreas brasileiras. Brasília: Embrapa Informação Tecnológica; Colombo, PR: Embrapa Florestas, 2003. 1039p.

CARPANEZZI, A. A.; NEVES, E. J. M.; AGUIAR, A. V.; SOUSA, V. A. Espécies lenhosas alternativas para fins econômicos no Paraná. In: SEMINÁRIO DE ATUALIZAÇÃO FLORESTAL, 2.; SEMANADE ESTUDOS FLORESTAIS, 11., 2010, Irati. Anais... Irati: UNICENTRO, 2010.9p. Disponível em: $<$ http:// anais.unicentro.br/sef2010/pdf/palestras/ Carpanezzi.pdf $>$. Acesso em: 03 nov. 2010. 
CHAVE, J.; ANDALO, C.; BROWN, S.; CAIRNS, M. A.; CHAMBERS, J. Q.; EAMUS, D.; FOLSTER, H.; FROMARD, F.; HIGUCHI, N.; KIRA, T.; LESCURE, J. P.; NELSON, B. W.; OGAWA, H.; PUIG, H.; RIERA, B.; YAMAKURA, T. Tree allometry and improved estimation of carbon stocks and balance in tropical forests. Oecologia, v. 145, n.1, p.87-99, 2005.

DRUMOND, M. A.; SALVIANO, L. M. C.; CAVALCANTI, N. DE B.; PEREIRA, L. G. R. Produção, distribuição da biomassa e composição bromatológica da parte aérea da faveleira.

Revista Brasileira de Ciências Agrárias, v.2, n.4, p.308-310, 2007.

JOSE, S.; GILLESPIE, A.R.; PALLARDY, S.G. Interspecific interactions in temperate agroforestry. Agroforestry Systems, v.61-62, n. 1, p.237-255, 2004.

FEREZ, A.P.C. Efeito de práticas silviculturais sobre as taxas iniciais de sequestro de carbono em plantios de restauração da Mata Atlântica. Piracicaba: 2010. 104f. Dissertação (Mestrado em Ciências Florestais) - Escola Superior de Agricultura Luiz de Queiroz, Piracicaba, 2010

FORSTER, H.W.; MELO, A.C.G. Biomassa aérea e de raízes de reflorestamentos heterogêneos no vale do Paranapanema, SP. IF. Série Registros, n.31, p.153-157, 2007.

GOUVEIA, T. C.; FLORSHEIM, S. M. B.; PASTORE, J. A.; AGUIAR, O. T.; LIMA, I. L. Morfologia, anatomia do lenho e densidade básica de Croton floribundus Spreng e Croton macrobothrys Baillon. IF. Série Registros, n.31, p.45-49, 2007. (Edição dos anais do $1^{\circ}$ Seminário de Iniciação Científica do Instituto Florestal, São Paulo, 2007)

GUTMANIS, D. Estoque de carbono e dinâmica ecofisiológica em sistemas silvipastoris. 2004. 142f. Tese (Doutorado em Ciências Biológicas) - Universidade Estadual Paulista, Rio Claro, 2004.

KAONGA, M.L.; BAYLISS-SMITH, T.P.

Allometric models for estimation of aboveground carbon stocks in improved fallows in eastern Zambia. Agroforestry Systems, v.78, p.217232,2010

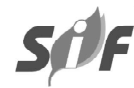

KUMAR, B.M.; GEORGE, S.J.; JAMALUDHEEN, V.; SURESH, T.K. Comparison of biomass production, tree allometry and nutrient use efficiency of multipurpose trees grown in woodlot and silvopastoral experiments in Kerala, India. Forest Ecology and Management, v.112, n.1, p.145-163, 1998.

MELOTTO, A.; NICODEMO, M.L.F.; BOCCHESE, R.A.; LAURA, V.A.; GONTIJO NETO, M.M.; SCHLEDER, D.D.; POTT, A.; PORFÍRIO-DA-SILVA, V. Sobrevivência e crescimento inicial em campo de espécies florestais nativas do Brasil Central indicadas para sistemas silvipastoris. Revista Árvore, v.33, p.425-432, 2009

NAIR, P.K.R. Classification of agroforestry systems. Agroforestry Systems, v.5, p.97128,1985

NICODEMO, M.L.F.; PORFÍRIO-DA-SILVA, V.; SANTOS, P.M.; VINHOLIS, M.M.B.; FREITAS, A.R.; CAPUTTI, G. Desenvolvimento inicial de espécies florestais em sistema silvipastoril na Região Sudeste. Pesquisa Florestal Brasileira, v.60, p.89-92, 2009.

PADILHA, D.R.C. Fitossociologia e estimativas da biomassa aérea e de carbono em Chaco Florestado no Brasil. 2011. 86f. Dissertação (Mestrado em Biologia Vegetal) - Universidade Federal de Mato Grosso do Sul, Campo Grande, 2011.

RÉ, D.S. Equações volumétricas e produção de madeira em plantios mistos visando à restauração da floresta estacional semidecidual. 2011. 65f. Dissertação (Mestrado em Ciência Florestal) Universidade Estadual Paulista, Botucatu, 2011.

RUSCHEL, A. R.; NODARI, E.S.; GUERRA, M.P.; NODARI, R.O. Evolução do uso e valorização das espécies madeiráveis da Floresta estacional decidual do Alto-Uruguai, SC. Ciência Florestal, v. 13, n.1, p.153-166, 2003.

SALIS, S. M.; ASSIS, M. A.; MATTOS, P. P.; PIÃO, A. C. S. Equações para estimar biomassa e volume de madeira em cerradóes do Pantanal da Nhecolândia, MS. Corumbá: Embrapa Pantanal, 2004. 4p. (Comunicado Técnico, 50).

Revista Árvore, Viçosa-MG, v.40, n.2, p.279-288, 2016 
Disponível em: <http://www.cpap. embrapa.br/ publicacoes/online/CT50.pdf $>$. Acesso em: 18 out. 2012

SCHNEIDER, P.R.; FINGER, C.A.G.; GIACOMELLI SOBRINHO, V.; SCHNEIDER, P.S.P. Determinação indireta do estoque de biomassa e carbono de povoamentos de acácianegra (Acacia mearnsii De Wild). Ciência Florestal, v. 15, n.4, p.391-402, 2005.

SILVA, G.C., SAMPAIO, E.V.S. Biomassas de partes aéreas em plantas da caatinga. Revista Árvore, v.32, n.3, p.567-575, 2008.

SOARES, C.P.B.; PAULA NETO, F.; SOUZA, A.L. Equações hipsométricas, volumétricas e de taper para onze espécies nativas. Revista Árvore, v.35,p.1039-1053, 2011.

SOARES, C.P.B.; PAULA NETO, F.; SOUZA, A.L. Dendrometria e inventário florestal. Viçosa, MG: UFV, 2007. v.1. 276p.

SOAVE, R.C.F. Influência de diferentes tiposde extração de resina na ciclagem de nutrients e no crescimento de indivìduos de Pinus elliottii Engelm. var. elliottii (Mogi Guaçú - SP). Rio Claro: 1990. Dissertação (Mestrado em Ciências Biológicas) - Instituto de Biociências, Universidade Estadual Paulista. Rio Claro, 1990.

TIEPOLO, G.; CALMON, M.; FERETTI, A.R. Measuring and monitoring carbon stocks at the Guaraqueçaba climate action project, Paraná, Brazil. In: International Symposium on Forest Carbon Sequestration and Monitoring. Taipei, Taiwan. Anais... Taipei: Taiwan Forestry Research Institute, 2002. p.98-115.

TILMAN, D.; BALZER, C.; HILL, J.; BEFORT, B.L. Global food demand and sustainable intensification of agriculture. PNAS, v.108, n.50, p. 20260-20264, 2011.

VENTURIN, R.P.; GUERRA, A.R.; MACEDO, R.L.G.; VENTURIN, N.; MESQUITA, H.A.

Sistemas agrossilvipastoris: origem, modalidades e modelos de implantação.

InformeAgropecuário, v. 31, p.16-24, 2010. 